\title{
Anticancer activity of 7-epiclusianone, a benzophenone from Garcinia brasiliensis, in glioblastoma
}

\author{
Leilane Sales ${ }^{1}$, Julia Alejandra Pezuk², Kleiton Silva Borges ${ }^{3}$, María Sol Brassesco ${ }^{4}$, Carlos Alberto Scrideli
} Luiz Gonzaga Tone ${ }^{3}$, Marcelo Henrique dos Santos ${ }^{5}$, Marisa Ionta ${ }^{6}$ and Jaqueline Carvalho de Oliveira ${ }^{1^{*}}$

\begin{abstract}
Background: Glioblastoma is the most common tumor of the central nervous system and one of the hardest tumors to treat. Consequently, the search for novel therapeutic options is imperative. 7-epiclusianone, a tetraprenylated benzophenone isolated from the epicarp of the native plant Garcinia brasiliensis, exhibits a range of biological activities but its prospect anticancer activity is underexplored. Thus, the aim of the present study was to evaluate the influence of 7-epiclusianone on proliferation, clonogenic capacity, cell cycle progression and induction of apoptosis in two glioblastoma cell lines (U251MG and U138MG).
\end{abstract}

Methods: Cell viability was measured by the MTS assay; for the clonogenic assay, colonies were stained with Giemsa and counted by direct visual inspection; For cell cycle analysis, cells were stained with propidium iodide and analyzed by cytometry; Cyclin A expression was determined by immunoblotting; Apoptotic cell death was determined by annexin $\vee$ fluorescein isothiocyanate labeling and Caspase-3 activity in living cells.

Results: Viability of both cell lines was drastically inhibited; moreover, the colony formation capacity was significantly reduced, demonstrating long-term effects even after removal of the drug. 7-epiclusianone treatment at low concentrations also altered cell cycle progression, decreased the $S$ and G2/M populations and at higher concentrations increased the number of cells at sub-G1, in concordance with the increase of apoptotic cells.

Conclusion: The present study demonstrates for the first time the anticancer potential of 7-epiclusianone against glioblastoma cells, thus meriting its further investigation as a potential therapeutic agent.

Keywords: Glioblastoma, 7-epiclusianone, Viability, Apoptosis, Cell cycle

\section{Background}

Glioblastoma (GBM) is the most aggressive and common glial tumors, and it represents the main type of primary cancer of the central nervous system in adults [1]. The actual standard treatment for GBM combines tumor resection, chemotherapy with temozolomide and radiotherapy [2]. However, despite management improvements, the outcome of patients remains extremely poor, with a mean life expectancy of approximately one year and a 2-year overall survival of only $15.4 \%$ [3]. Therefore,

\footnotetext{
* Correspondence: jaquelineunifal@gmail.com

1 Institute of Natural Sciences, Federal University of Alfenas, Rua Gabriel Monteiro da Silva, 700, 37130-000 Alfenas, MG, Brazil

Full list of author information is available at the end of the article
}

GBM remains as one of the hardest tumors to treat, making search for novel therapeutic options imperious.

Historically, natural products have been the foundation for the development of medical compounds and approximately $50 \%$ of anticancer drugs are still natural products or their derivatives $[4,5]$. Brazilian biodiversity offers many examples of common and rare plant life that deserves to be better explored. Among the variety of plant extracts described so far, 7-epiclusianone, a tetraprenylated benzophenone isolated from the epicarp of the native plant Garcinia brasiliensis (commonly known as bacupari), has traditionally been used in the folk medicine for the treatment of different diseases [6].

7-epiclusianone has shown important biological effects including anti-inflammatory $[7,8]$, antinociceptive $[7,9]$, 
antimicrobial [10, 11], antispasmodic [12], antianaphylactic [13] and antiprotozoal activities [14]. On the other hand, the potential anticancer and apoptotic effect is underexplored.

Based on such findings, the present study points 7 epiclusianone as a potential antineoplastic compound, demonstrating its influence on growth, cell cycle dynamics, apoptosis and colony formation ability against glioblastoma cells.

\section{Methods}

\section{Cell culture conditions}

The adult human GBM cell lines U138MG ( $553^{\text {mut }}$, PTEN $^{\text {mut }}$, p14ARF/p16 $6^{\text {del }}$, high MGMT levels) and U251MG (p53 ${ }^{\text {wt }}$, PTEN $^{\text {null }}, p 14 A R F / p 16^{\text {del }}$, low MGMT levels) were purchased from the American Type Culture Collection, USA. Cell cultures were maintained in DMEM (Dulbecco's Modified Eagle's Minimum Essential Medium, Sigma, CA, USA) supplemented with $10 \%$ fetal bovine serum (FBS, Cultilab, Sao Paulo, Brazil) and grown in a $37^{\circ} \mathrm{C}$ humidified incubator containing $5 \% \mathrm{CO}_{2}$.

\section{Isolation and characterization of 7-epiclusianone}

The fruits of Garcinia brasiliensis, after identification of plant material by Dr. João Augusto Alves Meira Neto, were collected from trees growing under controlled conditions at the herbarium of the Federal University of Viçosa - UFV (latitude 20 $45^{\prime} 14^{\prime \prime}$ south and longitude $42^{\circ} 52^{\prime} 55^{\prime \prime}$ west), Minas Gerais state, Brazil, where the voucher specimen (\#VIC2604) is deposited.

To obtain the extract, $1000 \mathrm{~g}$ of G. brasiliensis fruit epicarps were dried at $40{ }^{\circ} \mathrm{C}$ in a forced air oven for $48 \mathrm{~h}$. Dried and powdered epicarps were milled and extracted by maceration using EtOH $(3 \mathrm{~L})$ during $24 \mathrm{~h}$. Evaporation of the solvent under reduced pressure at $45{ }^{\circ} \mathrm{C}$ afforded the crude EtOH extract, which was chromatographed on silica gel (230-400 mesh) column and eluted with crescent polarity mixtures of (n-hexane, n-hexane-ethyl acetate (95:5), n-hexane-ethyl acetate (80:20), n-hexane-ethyl acetate (50:50), n-hexane-ethyl acetate (20:80) and ethanol) to give 25 fractions. These fractions were pooled into four groups according to their similarities after the analysis using thin layer chromatography (TLC) and compared to the standard 7-epiclusianone previously isolated. Fractions 4-10 were chromatographed on a silica gel (230-400 mesh) column $(8 \times 100 \mathrm{~cm})$ eluted with the same crescent polarity mixtures of n-hexane/ethyl-acetate and ethyl-acetate/ethanol to purify the prenylated benzophenone 7 -epiclusianone with a yield of $5 \%$. Its structure (Fig. 1) was identified as the polyprenylated benzophenone 7-epiclusianone [(1R, 5R,7R)-3-benzoyl-4-hydroxy-8,8-dimethyl-1,5,7-tris(3methylbut-2-en-1-yl) bicyclo[3.3.1]non-3-ene-2,9-dione] using infrared, ultraviolet, and mass spectra data and

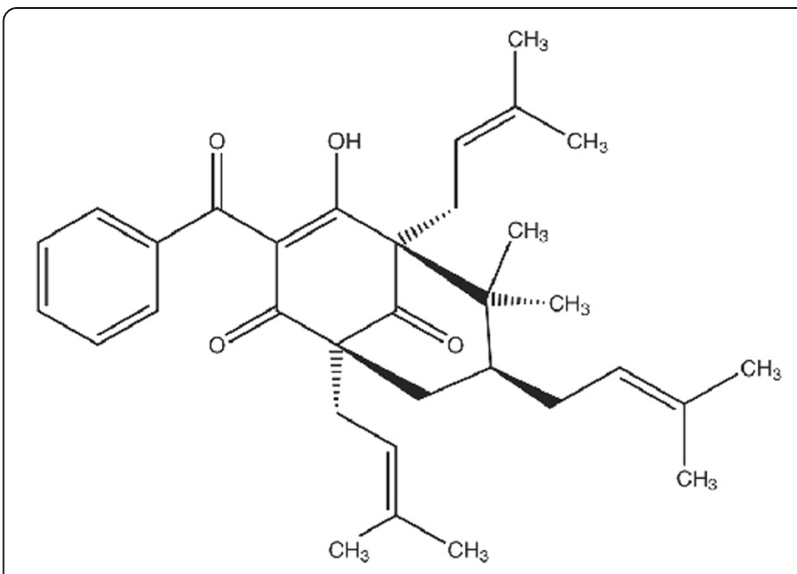

Fig. 1 Chemical structure of 7-epiclusianone

nuclear magnetic resonance spectroscopy, and its molecular geometries established using single crystal X-ray diffraction (XRD) analysis. The purity level was $>99.85 \%$ as determined by HPLC $[15,16]$.

For in vitro testing, 7-epiclusianone was dissolved in dimethyl sulfoxide (DMSO), and this stock solution was diluted in fresh medium at the appropriated concentrations immediately before of use. Vehicle alone was used as control and the final concentration of the solvent did not exceed $0.5 \%(\mathrm{v} / \mathrm{v})$.

\section{Cell viability}

Cells were plated on 96 -wells at $5 \times 10^{3}$. After attachment $(24 \mathrm{~h})$, the cells were treated for $48 \mathrm{~h}$ with 7-epiclusianone at different concentrations $(10 \mu \mathrm{M}, 20 \mu \mathrm{M}, 30 \mu \mathrm{M}$ or $40 \mu \mathrm{M})$. The Promega ${ }^{\circ}$ non-radioactive cell proliferation assay was used to determinate cell viability. This assay measures the amount of formazan produced from [3-(4,5-dimethylthiazol-2-yl)-5-(3-carboxymethoxyphenyl)2-(4-sulfophenyl)-2H-tetrazolium, inner salt, MTS)] by the dehydrogenase enzymes of metabolically active cells (Promega, Madison, WI, USA). Thus, the quantity of formazan produced (as measured by the absorbance at $490 \mathrm{~nm}$ ) is directly proportional to the number of living cells. Absorbance values of the treated cells were compared with the absorbance values of untreated cells. The experiments were conducted in triplicate wells and repeated twice. Means \pm standard deviations (SD) were calculated. The $\mathrm{IC}_{50}$ value was determined from non-linear regression using GraphPad Prism (GraphPad Software, Inc., San Diego, CA, USA).

\section{Colony formation assay}

Clonogenic formation assay was performed according to Franken et al. [17]. Two hundred cells were seeded in $35 \mathrm{~mm}$ plates. After $24 \mathrm{~h}$, cells were treated with 7-epiclusianone for $8 \mathrm{~h}$ and subsequently were incubated for 10 days with drug-free medium. After that period, colonies 
were fixed and stained with Giemsa (3\%). Only colonies with $>50$ cells were counted by direct visual inspection with a stereo microscope at $20 \times$ magnification. Assays were performed in triplicate.

\section{Cell cycle analysis}

For cell cycle analysis, $2 \times 10^{5}$ cells were seeded on $25 \mathrm{~cm}^{2}$ flasks and treated for $48 \mathrm{~h}$. Cells were then trypsinized and fixed in $70 \%$ ethanol, stained with propidium iodide, and analyzed with a Guava Personal Cell Analysis system (Guava Technologies, Hayward, CA, USA) according to the protocol provided by the manufacturer. Percentages of cells in sub-G1, G0/G1, S, or G2/M phase were determined and processed using the GUAVA Cytosoft software, version 4.2.1. Assays were performed three times on separate occasions.

\section{Immunoblot}

Both cell lines were treated with $10 \mu \mathrm{M}$ and $40 \mu \mathrm{M}$ for $48 \mathrm{~h}$. Cells were then lysed in lysis buffer (RIPA; Sigma Chemical Co.; $10 \%$ protease, and $10 \%$ phosphatase) and stored at $-80{ }^{\circ} \mathrm{C}$ until use.

Anti-Cyclin-A (sc-751, 1:1000) and anti-GAPDH (sc47724, 1:1000) antibodies were purchased from Santa Cruz Biotechnology (Santa Cruz, CA, USA). Equal amounts of protein $(40 \mathrm{mg})$ were size-fractionated by $12 \%$ SDS-PAGE, blotted onto a nitrocellulose membrane (Amersham Hybond $^{\mathrm{mm}}$ ECL $^{\mathrm{m}}$, GE Healthcare) and incubated in Tris-buffered saline- $0.1 \%$ Tween-20 (TBS-T) containing $5 \%(\mathrm{w} / \mathrm{v})$ dried non-fat milk for $1 \mathrm{~h}$ at room temperature. After blocking and washing in TBS-T with $0.1 \%$ Tween 20 for $30 \mathrm{~min}$, each membrane was incubated overnight with appropriately diluted primary antibodies. After incubation, the membrane was washed three times in TPBS-T with $0.1 \%$ Tween 20 and bound to a biotin-labeled horseradish peroxidase-conjugated speciesspecific secondary antibody (AbCam, San Francisco, CA, USA). The complexes were visualized using an enhanced chemiluminescence reagent (ECL; Amersham, Uppsala, Sweden).

\section{Apoptosis assay}

Apoptotic cell death was determined by annexin V fluorescein isothiocyanate labeling (BD Biosciences Pharmigen, San Jose, CA, USA). Briefly, cells were grown in $25 \mathrm{~cm}^{2}$ tissue culture flasks and treated with 7-epiclusianone for $48 \mathrm{~h}$ cells were then trypsinized and centrifuged at 1,000 rpm for $5 \mathrm{~min}$ at $4{ }^{\circ} \mathrm{C}$, washed with ice-cold PBS, and then $2 \times 10^{5}$ cells were resuspended in $300 \mu \mathrm{l}$ of $1 \times$ annexin $\mathrm{V}$ binding buffer (BD Biosciences Pharmigen). Cells were stained with $5 \mu \mathrm{l}$ annexin $\mathrm{V}$ fluorescein isothiocyanate and $50 \mu \mathrm{l}$ of propidium iodide $(50 \mu \mathrm{mol} / \mathrm{L})$, and immediately read. At least 10,000 events were analyzed using a BD FACSCalibur flow cytometer
(BD Biosciences Pharmigen). Assays were performed in triplicate.

Apoptotic cell death was also determined by analysis of caspase activation. $5 \times 10^{4}$ cells were seeded on 6 -well plates containing $3 \mathrm{~mL}$ of culture medium. After $24 \mathrm{~h}$, the medium was replaced and cells treated with $40 \mu \mathrm{M}$ of 7-epiclusianone or vehicle only and cultured for additional $48 \mathrm{~h}$. Caspase activation was determined using the NucView 488 Caspase-3 Detection in Living Cells kit (Biotium Inc. \#30029) according to the manufacturer's instructions. Five hundred nuclei per treatment were analyzed by fluorescence microscopy.

\section{Statistical analysis}

Statistical analyses were performed using the SigmaStat 3.5 software (Jandel Scientific Company, San Rafael, CA, USA). One-way repeated measures analysis of variance followed by the Holm-Sidak pairwise multiple comparison were used to establish any significant differences between groups. For caspase activation analysis, Student's $t$-test was used. All tests were carried out for $\alpha=0.05$.

\section{Results and discussion}

7-epiclusianone significantly inhibited cell viability in both GBM lines tested when compared to control in a concentration-dependent manner $(\mathrm{p}<0.01)$ (Fig. 2a and b). The concentration required to induce $50 \%$ inhibition of cell growth $\left(\mathrm{IC}_{50}\right)$ after $48 \mathrm{~h}$ of treatment was $23.00 \pm$ $0.32 \mu \mathrm{M}$ in U251MG $\left(\mathrm{r}^{2}=0.99\right)$ and $18.52 \pm 0.50 \mu \mathrm{M}$ $\left(\mathrm{r}^{2}=0.98\right)$ in U138MG.

7-epiclusianone treatment also reduced the colony formation capacity for both cell GBM lines when compared to control at $20 \mu \mathrm{M}$ and $30 \mu \mathrm{M}(p<0.01)$, demonstrating long-term effects even after removal of the drug (Fig. 2c-f).

Cell cycle analysis showed that 7-epiclusianone is effective in inducing cell cycle arrest and/or cell death, however these effects are concentration-dependent. Increased G1 population with concomitant decreased $\mathrm{G} 2 / \mathrm{M}$ populations was observed in U251MG cultures treated with 7epiclusianone at $10 \mu \mathrm{M}$, in U138MG there were also decrease in $\mathrm{S}$ and G2/M populations. When higher concentration of 7-epiclusianone was used $(40 \mu \mathrm{M})$, a significant increase in Sub-G1 population was observed for both cell lines (Fig. 3a and b, Table 1).

Cell cycle arrest was accompanied by decreased CCNA (cyclin A) expression (Fig. 3c), which is a cell cycle regulatory protein repressed during $\mathrm{G} 1$ phase and induced at S-phase [18]. Furthermore, ectopically expressed cyclin A overcomes G1 arrest in vitro [19], suggesting that 7-epiclusianone induced G1-phase arrest is at least partially caused by cyclin A down regulation.

Besides G1 arrest, after high dose treatment $(40 \mu \mathrm{M})$ cell cycle analysis showed increase in the sub-G1 population. 

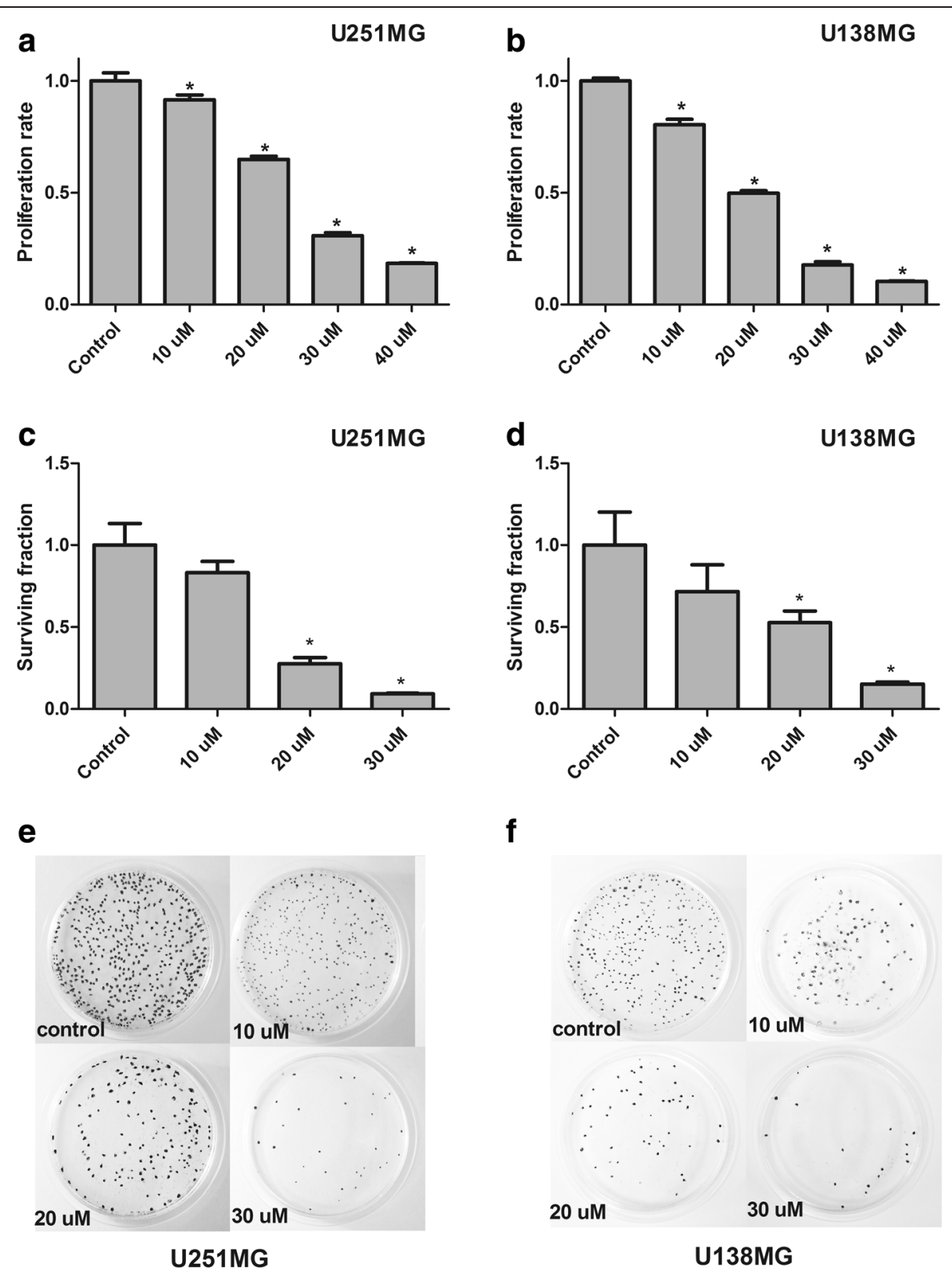

Fig. 2 7-epiclusianone treatments inhibit growth and clonogenic capacity. a, b Growth inhibition in U251MG and U138MG cell lines treated with 7-epiclusianone at the indicated concentrations for $48 \mathrm{~h}$ (MTS assay); (c-f) 7-epiclusianone potently abrogated the clonogenic capacity of both glioblastoma cell lines $\left({ }^{*} p<0.01\right)$

Considering the results obtained, we also investigated whether cell death detected would be due to apoptosis induction. Annexin V was used for monitoring cells in apoptosis and the $40 \mu \mathrm{M}$ treatment mediated a significant increase of positive cells to $18.8 \%$ for U251MG and to $21.8 \%$ for U138MG $(p<0.01)$ after 48 h (Fig. 4a and c-f). This result was also confirmed by increased level of cell caspase-3 activity (Fig. 4b). Additionally, the ratio of proliferation and apoptosis (annexin $\mathrm{V}$ positive cells) in GBM cells were 22.83 (U251MG) and 19.92 (U138MG) before treatment, after $40 \mu \mathrm{M}$ 7-epiclusianone exposition, the ratio strongly decreased for 1.05 in U251MG and 0.48 in U138MG cell lines.

The Clusiaceae family is frequently found in tropical areas and comprises about 40 genera and 1200 species, with about 400 species of Garcinia genius [10]. Several benzophenones extracted from Garcinia spp. such as G. indica, G. xanthochymus, G. purpurea, G. macrophylla, G. mangostana, G. pyrifera, and G. yunnanensis have previously exhibited cytotoxic activity against various tumor types, including prostate, ovarian, colon, leukemia and cervical cancer [20-22]. 


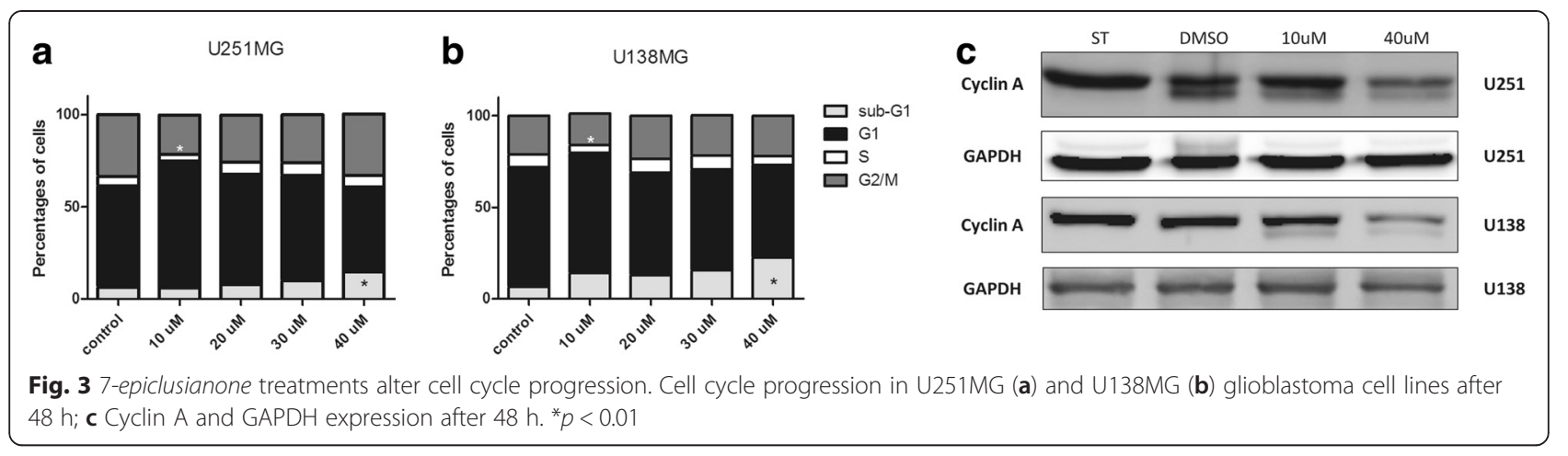

Garcinia brasiliensis fruits have long been used as an alternative treatment in Brazilian folk medicine. In the present study, we showed that its derivative, 7-epiclusianone, diminishes cell viability, alters cell cycle progression, and increases apoptosis in GBM, one of the most aggressive tumors and with limited treatment options.

Table 1 Cell cycle analysis of glioblastoma cell lines after treatment with 7-epiclusianone

\begin{tabular}{|c|c|c|c|c|}
\hline & \multicolumn{2}{|c|}{ U251MG } & \multicolumn{2}{|c|}{ U138MG } \\
\hline \multicolumn{5}{|l|}{ Sub-G1 (\%) } \\
\hline Control & 6.35 & \pm 0.92 & 6.45 & \pm 3.68 \\
\hline $10 \mu \mathrm{M}$ & 5.92 & \pm 3.00 & 13.98 & \pm 6.14 \\
\hline $20 \mu \mathrm{M}$ & 7.80 & \pm 1.00 & 12.99 & \pm 0.81 \\
\hline $30 \mu \mathrm{M}$ & 9.88 & \pm 1.09 & 15.66 & \pm 2.82 \\
\hline $40 \mu \mathrm{M}$ & 14.74 & $\pm 0.94^{*}$ & 22.50 & $\pm 2.45^{*}$ \\
\hline \multicolumn{5}{|l|}{ G1 (\%) } \\
\hline Control & 54.97 & \pm 2.76 & 65.54 & \pm 3.86 \\
\hline $10 \mu \mathrm{M}$ & 68.94 & $\pm 2.34^{*}$ & 65.70 & \pm 4.20 \\
\hline $20 \mu \mathrm{M}$ & 59.67 & \pm 3.82 & 55.99 & $\pm 0.54^{*}$ \\
\hline $30 \mu \mathrm{M}$ & 57.02 & \pm 2.97 & 54.92 & $\pm 0.68^{*}$ \\
\hline $40 \mu \mathrm{M}$ & 45.77 & $\pm 1.49^{*}$ & 50.72 & $\pm 2.58^{*}$ \\
\hline \multicolumn{5}{|l|}{ S (\%) } \\
\hline Control & 5.07 & \pm 1.07 & 6.83 & \pm 0.73 \\
\hline $10 \mu \mathrm{M}$ & 3.59 & \pm 1.63 & 4.32 & $\pm 0.76^{*}$ \\
\hline $20 \mu \mathrm{M}$ & 6.77 & \pm 0.41 & 7.44 & \pm 0.75 \\
\hline $30 \mu \mathrm{M}$ & 6.93 & \pm 0.39 & 7.45 & \pm 0.92 \\
\hline $40 \mu \mathrm{M}$ & 6.23 & \pm 1.92 & 4.74 & $\pm 0.17^{*}$ \\
\hline \multicolumn{5}{|l|}{ G2/M (\%) } \\
\hline Control & 33.79 & \pm 2.34 & 21.24 & \pm 0.50 \\
\hline $10 \mu \mathrm{M}$ & 21.36 & $\pm 1.05^{*}$ & 17.25 & $\pm 3.05^{*}$ \\
\hline $20 \mu \mathrm{M}$ & 25.44 & $\pm 2.99^{*}$ & 23.51 & \pm 0.90 \\
\hline $30 \mu \mathrm{M}$ & 26.10 & $\pm 1.66^{*}$ & 22.32 & \pm 3.65 \\
\hline $40 \mu \mathrm{M}$ & 33.62 & \pm 2.28 & 21.99 & \pm 1.92 \\
\hline
\end{tabular}

Percentages of cells in Sub-G1, G1, S and G2/M phases are expressed as mean \pm standard deviation ${ }^{*} p<0.05$
So far, few articles suggested a potential antiproliferative effect of $G$. brasiliensis after 7-epiclusianone treatment of human cancer cell lines, including melanoma, kidney, ovarian, prostate and lung [23, 24].

In A549 lung cells, 7-epiclusianone treatment also induced apoptosis and cell cycle arrest in G1/S transition. Additionally, the cytotoxic activity of 7-epiclusianone in normal fibroblasts (CCD-1059Sk) was also evaluated and $\mathrm{IC}_{50}$ value was approximately $58 \mu \mathrm{M}$, 2.5 and 3.2 times higher than for the cancer cell lines tested herein, U251MG and U138MG [24].

Similar cytotoxic activities have been described for another polyisoprenylated benzophenone isolated and purified from G. xanthochymus which arrests the cell-cycle in G1-phase and induces apoptosis in colon cancer cell lines [25]. Apoptosis has also been evidenced after treatment with benzophenones extracted from G. xanthochymus [26], from G. yunnanensis [27], and from G. purpurea [28] in many solid tumors and leukemia cells. Comparatively, Garcinol (obtained from G. indica), the most cited natural benzophenone in the literature, has repeatedly demonstrated to decrease cell viability and induce apoptosis of cancer cells $[29,30]$. This compound also decreased the colony forming ability of prostate and pancreatic cancer cell lines, suggesting a possible application against metastatic disease [31].

It is well known that GBM treatment outcome is often hampered by the inherent invasive properties of the tumor, thus the clonogenic capacity of cells after treatment is an important aspect for testing potential therapeutic compounds. Herein, 7-epiclusianone treatment for only $8 \mathrm{~h}$ significantly reduced the colony formation capacity of GBM cells, demonstrating longterm effects even after removal of the drug.

Another benzophenone derived from the Malaysian G. hombroniana, 2,3',4,5'-tetrahydroxy-6-methoxybenzophenone, has also presented cytotoxic effects on the DBTRG cell line which is derived from a 56-year-old woman with GBM. Most interestingly, the compound was found to be more toxic towards glioma cells as compared to other cell lines of different origin including MCF-7 (breast 


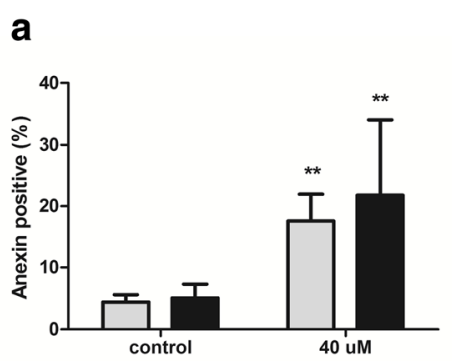

C
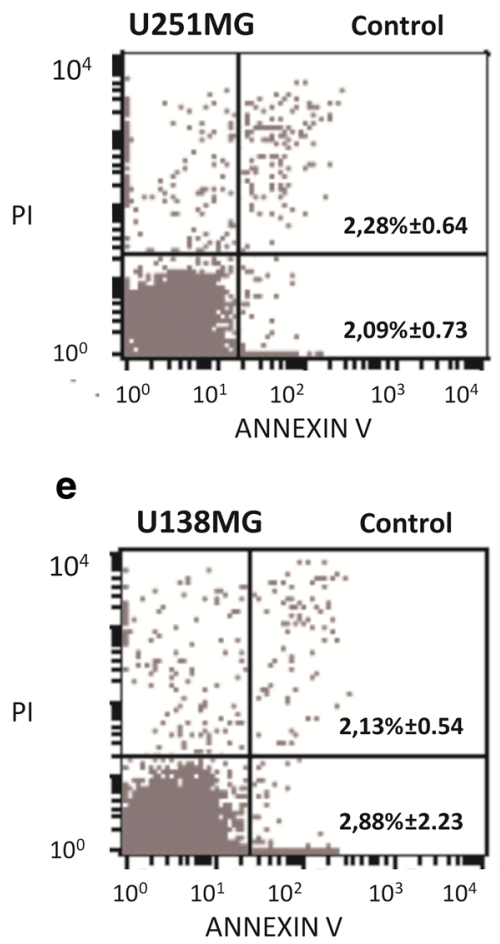

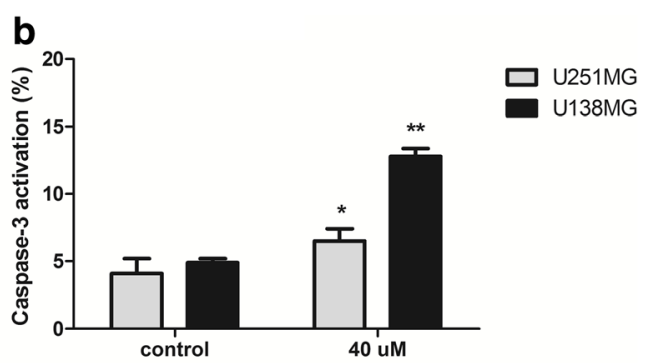

d

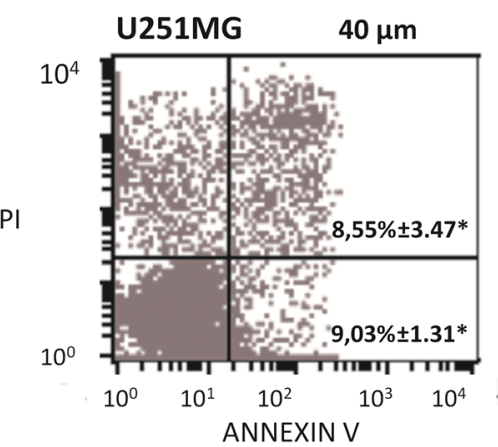

f

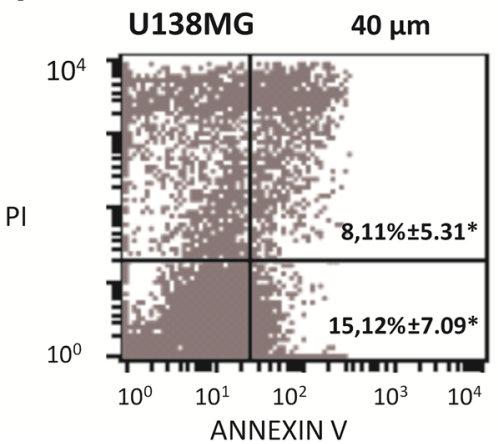

Fig. 4 7-epiclusianone treatments alter apoptotic rates. a, c-f Increased Annexin $V$ positive cells after treatment with 7-epi-clusianone in glioblastoma (GBM) cells lines; $\mathbf{b}$ Increased caspase-3 activation rates after treatment with 7-epiclusianone in GBM cells lines (data are expressed as the mean-SD of all cell lines). ${ }^{*} p<0.05,{ }^{* *} p<0.01$. Pl, propidium iodide

cancer), U2OS (osteosarcoma) and PC-3 (prostate cancer) [32].

In the present study, we investigated 7-epiclusianone in glioma cells mainly due to extremely poor outcome of patients caused for few chemotherapy options available. However, the numerous antitumor effects described for other natural benzophenone recommend future investigation of 7-epiclusianone also in other tumor types.

Even though the mechanisms through which benzophenones impair cell growth and induce apoptosis are still under investigation, some studies suggest an antimicrotubule action during cell division or the intensification of caspase- 3 activity [25, 28, 29]. Other mechanisms such as inhibition of histone acetyltranferase activity [33], inhibition of kinase activity [34], or inducing DNA damage [35] have also been suggested.

\section{Conclusions}

The results presented herein point 7-epiclusianone as an important natural benzophenone with antineoplastic activity in a glioblastoma model, a tumor with inherent chemoresistance, demonstrating influence on cell growth, cell cycle dynamics, apoptosis and colony formation ability. However, further studies should be conducted to investigate the molecular mechanisms underneath the cytotoxic activity of this benzophenone, pharmacokinetics in human condition and the prospect of using it for the treatment of other tumor types. 


\section{Competing interests}

The authors declare that they have no competing interests.

\section{Authors' contributions}

JCO and MI designed the study and supervised the project; MHS collected the plant and carried out the extraction; LS, JAP, KSB, MSB, JCO performed laboratory analyses; CAS and LGT provided reagents and helped to supervise the research. All authors read and approved the final version of the manuscript.

\section{Acknowledgements}

This study was supported by the following Public Research Agencies: FAPEMIG, FAPESP, CNPq and CAPES.

\section{Author details}

${ }^{1}$ Institute of Natural Sciences, Federal University of Alfenas, Rua Gabriel Monteiro da Silva, 700, 37130-000 Alfenas, MG, Brazil. Molecular Oncology Center, Sirio Libanes Hospital, Rua Dona Adma Jafet, 115, 01308-050 Sao Paulo, SP, Brazil. 'Department of Paediatrics, Ribeirão Preto Medical School, University of São Paulo, Av. Bandeirantes, 3900, 14049-900 Ribeirão Preto, SP, Brazil. ${ }^{4}$ Department of Biology, Faculty of Philosophy, Sciences and Letters at Ribeirão Preto, University of São Paulo, Av. Bandeirantes, 3900, 14049-900 Ribeirão Preto, SP, Brazil. Institute of Chemistry, Federal University of Viçosa, Avenida Peter Henry Rolfs, s/n, 36570-900 Viçosa, MG, Brazil. ${ }^{6}$ Institute of Biomedical Sciences, Federal University of Alfenas, Rua Gabriel Monteiro da Silva, 700, 37130-000 Alfenas, MG, Brazil.

\section{Received: 23 July 2015 Accepted: 12 October 2015}

Published online: 30 October 2015

\section{References}

1. Lim SK, Llaguno SR, McKay RM, Parada LF. Glioblastoma multiforme: a perspective on recent findings in human cancer and mouse models. BMB Rep. 2011;44(3):158-64.

2. Gilbert MR. Recurrent glioblastoma: a fresh look at current therapies and emerging novel approaches. Semin Oncol. 2011;38 Suppl 4:S21-33.

3. Guckenberger M, Mayer M, Buttmann M, Vince GH, Sweeney RA, Flentje M. Prolonged survival when temozolomide is added to accelerated radiotherapy for glioblastoma multiforme. Strahlenther Onkol. 2011;187(9):548-54.

4. Newman DJ, Cragg GM. Natural products as sources of new drugs over the 30 years from 1981 to 2010. J Nat Prod. 2012;75(3):311-35.

5. Gul MZ, Ahmad F, Kondapi AK, Qureshi IA, Ghazi IA. Antioxidant and antiproliferative activities of Abrus precatorius leaf extracts-an in vitro study. BMC Complement Altern Med. 2013;13:53.

6. Corrêa MP. Dicionário das Plantas Úteis do Brasil e das Plantas Exóticas Cultivadas. 1st ed. Rio de Janeiro: Imprensa Nacional; 1978.

7. Santa-Cecília FV, Freitas LA, Vilela FC, Veloso Cde C, da Rocha CQ, Moreira $M E$, et al. Antinociceptive and anti-inflammatory properties of 7epiclusianone, a prenylated benzophenone from Garcinia brasiliensis. Eur J Pharmacol. 2011;670(1):280-5.

8. Santa-Cecília FV, Santos GB, Fuzissaki CN, Derogis PB, Freitas LA, Gontijo VS, et al. 7-epiclusianone, the natural prenylated benzophenone, inhibits superoxide anions in the neutrophil respiratory burst. J Med Food. 2012;15(2):200-5

9. Santa-Cecília FV, Vilela FC, da Rocha CQ, Dias DF, Cavalcante GP, Freitas LA, et al. Anti-inflammatory and antinociceptive effects of Garcinia brasiliensis. J Ethnopharmacol. 2011;133(2):467-73.

10. Naldoni FJ, Claudino AL, Cruz JW, Chavasco JK, Faria e Silva PM, Veloso MP et al. Antimicrobial activity of benzophenones and extracts from the fruits of Garcinia brasiliensis. J Med Food. 2009;12(2):403-7.

11. Murata RM, Branco-de-Almeida LS, Franco EM, Yatsuda R, dos Santos MH, de Alencar SM, et al. Inhibition of Streptococcus mutans biofilm accumulation and development of dental caries in vivo by 7-epiclusianone and fluoride. Biofouling. 2010;26(7):865-72.

12. Coelho LP, Serra MF, Pires AL, Cordeiro RS, Rodrigues e Silva PM, dos Santos $\mathrm{MH}$, et al. 7-Epiclusianone, a tetraprenylated benzophenone, relaxes airway smooth muscle through activation of the nitric oxide-cGMP pathway. J Pharmacol Exp Ther. 2008;327(1):206-14.

13. Neves JS, Coelho LP, Cordeiro RS, Veloso MP, Rodrigues e Silva PM, dos Santos MH, et al. Antianaphylactic properties of 7-epiclusianone, a tetraprenylated benzophenone isolated from Garcinia brasiliensis. Planta Med. 2007;73(7):644-9.

14. Pereira IO, Marques MJ, Pavan AL, Codonho BS, Barbiéri $C L$, Beijo LA, et al. Leishmanicidal activity of benzophenones and extracts from Garcinia brasiliensis Mart. fruits. Phytomedicine. 2010;17(5):339-45.

15. Piccinelli AL, Cuesta-Rubio O, Chica MB, Mahmood N, Pagano B, Pavone $M$, et al. Structural revision of clusianone and 7-epiclusianone and anti-HIV activity of polyisoprenylated benzophenones. Tetrahedron. 2005;61:8206-11.

16. Derogis PB, Martins FT, de Souza TC, de C Moreira ME, Souza Filho $J D$, Doriguetto AC, et al. Complete assignment of the $1 \mathrm{H}$ and $13 \mathrm{C}$ NMR spectra of garciniaphenone and keto-enol equilibrium statements for prenylated benzophenones. Magn Reson Chem. 2008;46(3):278-82

17. Franken NA, Rodermond HM, Stap J, Haveman J, van Bree C. Clonogenic assay of cells in vitro. Nat Protoc. 2006;1(5):2315-9.

18. Blanchard JM. Cyclin A2 transcriptional regulation: modulation of cell cycle control at the G1/S transition by peripheral cues. Biochem Pharmacol. 2000:60:1179-84

19. Weiss C, Faust D, Schreck I, Ruff A, Farwerck T, Melenberg A, et al. TCDD deregulates contact inhibition in rat liver oval cells via Ah receptor, JunD and cyclin A. Oncogene. 2008;27:2198-207.

20. Acuña UM, Jancovski N, Kennelly EJ. Polyisoprenylated benzophenones from Clusiaceae: potential drugs and lead compounds. Curr Top Med Chem. 2009:9(16):1560-80.

21. Aisha AF, Abu-Salah KM, Ismail Z, Majid AM. In vitro and in vivo anti-colon cancer effects of Garcinia mangostana xanthones extract. BMC Complement Altern Med. 2012;12:104

22. Biloa Messi B, Ho R, Meli Lannang A, Cressend D, Perron K, Nkengfack AE, et al. Isolation and biological activity of compounds from Garcinia preussii. Pharm Biol. 2014;52(6):706-11.

23. Murata RM, Yatsuda R, dos Santos MH, Kohn LK, Martins FT, Nagem TJ, et al. Antiproliferative effect of benzophenones and their influence on cathepsin activity. Phytother Res. 2010;24(3):379-83.

24. Ionta M, Ferreira-Silva GA, Niero EL, Costa ÉD, Martens AA, Rosa W, et al. 7-Epiclusianone, a Benzophenone Extracted from Garcinia brasiliensis (Clusiaceae), Induces Cell Cycle Arrest in G1/S Transition in A549 Cells. Molecules. 2015;20(7):12804-16.

25. Protiva P, Hopkins ME, Baggett S, Yang H, Lipkin M, Holt PR, et al. Growth inhibition of colon cancer cells by polyisoprenylated benzophenones is associated with induction of the endoplasmic reticulum response. Int J Cancer. 2008:123(3):687-94

26. Baggett S, Protiva P, Mazzola EP, Yang H, Ressler ET, Basile MJ, et al. Bioactive benzophenones from Garcinia xanthochymus fruits. J Nat Prod. 2005;68(3):354-60

27. Xu G, Feng C, Zhou Y, Han QB, Qiao CF, Huang SX, et al. Bioassay and ultraperformance liquid chromatography/mass spectrometry guided isolation of apoptosis-inducing benzophenones and xanthone from the pericarp of Garcinia yunnanensis Hu. J Agric Food Chem. 2008;56(23):11144-50.

28. Matsumoto K, Akao Y, Kobayashi E, Ito T, Ohquchi K, Tanaka T, et al. Cytotoxic benzophenone derivatives from Garcinia species display a strong apoptosis-inducing effect against human leukemia cell lines. Biol Pharm Bull. 2003;26(4):569-71

29. Hong J, Kwon SJ, Sang S, Ju J, Zhou JN, Ho CT, et al. Effects of garcinol and its derivatives on intestinal cell growth: Inhibitory effects and autoxidationdependent growth-stimulatory effects. Free Radic Biol Med. 2007:42(8):1211-21.

30. Parasramka MA, Gupta SV. Synergistic effect of garcinol and curcumin on antiproliferative and apoptotic activity in pancreatic cancer cells. J Oncol. 2012;2012:709739.

31. Ahmad A, Wang Z, Wojewoda C, Ali R, Kong D, Maitah MY, et al. Garcinolinduced apoptosis in prostate and pancreatic cancer cells is mediated by NF- kappaB signaling. Front Biosci (Elite Ed). 2011;3:1483-92.

32. Jamila N, Khairuddean M, Yaacob NS, Kamal NN, Osman H, Khan SN, et al. Cytotoxic benzophenone and triterpene from Garcinia hombroniana. Bioorg Chem. 2014;54:60-7.

33. Balasubramanyam K, Altaf M, Varier RA, Swaminathan V, Ravindran A, Sadhale PP, et al. Polyisoprenylated benzophenone, garcinol, a natural histone acetyltransferase inhibitor, represses chromatin transcription and alters global gene expression. J Biol Chem. 2004;279(32):33716-26. 
34. Díaz-Carballo D, Malak S, Freistühler M, Elmaagacli A, Bardenheuer W, Reusch HP. Nemorosone blocks proliferation and induces apoptosis in leukemia cells. Int J Clin Pharmacol Ther. 2008;46(8):428-39.

35. Wu CC, Yen MH, Yang SC, Lin CN. Phloroglucinols with antioxidant activity and xanthonolignoids from the heartwood of Hypericum geminiflorum. J Nat Prod. 2008;71(6):1027-31.

Submit your next manuscript to BioMed Central and take full advantage of:

- Convenient online submission

- Thorough peer review

- No space constraints or color figure charges

- Immediate publication on acceptance

- Inclusion in PubMed, CAS, Scopus and Google Scholar

- Research which is freely available for redistribution 